\title{
Comparisons Of Proctored Versus Non- Proctored Testing Strategies In Graduate Distance Education Curriculum
}

\author{
Diane J. Prince, Clayton State University, USA \\ Richard A. Fulton, Troy University, USA \\ Thomas W. Garsombke, Claflin University, USA
}

\begin{abstract}
The authors studied the testing pattern grades in four e-campus courses at Troy University with 76 graduate students. In their research, the authors found significant differences in average test grade scores between tests taken electronically without a proctor as compared to those administered using a live or a remote proctor overall. To control for differences among courses, a statistical test was solely conducted on the courses which had the same instructor, same text, and similar tests with comparable results; students scored significantly lower on proctored exams versus non-proctored exams. To enhance the quality of courses in the online environment, the researchers recommend several "best practices" pedagogical strategies based on their findings and an extensive literature review.
\end{abstract}

Keywords: Testing, Proctored Tests, Distance Education, Online Education, Curriculum, Internet, Pedagogical Strategies

\section{INTRODUCTION}

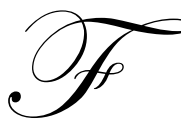

ueled by intense competition in higher education as well as the increasing popularity and the widespread availability of the Internet, distance learning is becoming the mode of choice for many university courses and programs. It is getting difficult to find a major American university or college which does not offer distance learning to their students. In 2003, Lawrence (2003, p. 2) found that enrollments topped 1.3 million "in over 50,000 distance-learning course offerings". The Chronicle of Higher Education estimates that nearly 1 in 2 university or college students in the U.S. has taken a course online and nearly 1 in 10 take their entire program online (IT ..., 2008).

As online education increases in use, faculty and administrators alike are questioning whether the quality of the education experience in the online setting is equivalent to the quality of in-class courses. This study hopes to address the issue of quality in the online education environment and add empirical proof that proctored tests could add more rigor to the distance learning arena. In addition, this research project aims to increase the evidence and hopefully in a small way tackle Phipps \& Meisotis' (1999, p. 25) criticism that "there is a relative paucity of true, original research explaining or predicting phenomena related to distance learning."

\section{REVIEW OF THE LITERATURE}

\section{Technology Usage}

The use of technology seems to be of little question in the classroom. Online education is booming. The benefits are numerous. Online or distance education feedback from students on assignments can be gathered in real time and the professor can improve on the class while it is going on (Abraham, 1995, p. 145). Lawrence and Singhania (2004, p. 333) suggest that the boom in online education is directly linked to the use of technology since 
distance courses and programs can "reach a broader student audience and have the potential to address student needs better at significantly lower costs." Wadsworth et al. $(2007$, p. 6) explain that many universities are "transitioning their developmental education courses onto the Web to provide greater access for students and to reduce teaching loads".

As the technology becomes more sophisticated, faculty can use the technology to eliminate some of the problems associated with distance learning, for example, cheating and questionable identity of the student. Professors can catch cheaters and stop identity fraud through many different techniques tied to new technologies: cameras, remote proctors (which also have fingerprint and id checking mechanisms), proctored exams, by calling students on the telephone unexpectedly to assess progress, discuss a point further or to ask how the student found a piece of information (i.e. checking for plagiarism), and by checking paper content through an internet search engine or Turnitin software.

\section{Pros and Cons of Distance Education}

Although online or distance education is expanding and being embraced by more institutions of higher education than ever before, moving courses from the traditional classroom to an online setting fundamentally shifts human interaction, communication, and learning paradigms (Robles \& Braathen, 2002). There are a number of benefits that are part of distance learning's allure. In online courses, because of the nature of the environment, all communication is in writing and that increases the "academic rigor" in the assessment of writing and thinking skills since professors would probably see more writing and discussion samples. The professor can really get to know each student's work better than in an on-site class especially for the more reserved or quiet student who does not participate much. In the online environment, everyone is participating more equally. Carnavale (1999, p. A 47) finds that some professors ask students to write essays early in the class and that way they can "compare writing styles on a paper to the beginning essays to assess plagiarism".

The delivery platforms such as Blackboard, Vista and Web-CT have narrowed the variety of approaches in the online environment since they have similar basic functions of discussion board, chat rooms, group work (chat and discussion board), schedule/calendar of work, posting of website links, articles, powerpoint, video clips, electronic gradebook, assignment grading with feedback notes, and digital dropboxes where papers can be reviewed and uploaded with comments. Many publishers now have downloadable e- textbooks and learning packets with many student learning tools such as online quizzes, online libraries/articles, online powerpoints, chapter summaries, and faculty resources.

Although hybrid and online classes are on the upswing, drawbacks to distance learning include: potential for breakdowns - "web servers crash, FTP programs stop transferring files and some browsers may not support certain features"; technological barriers - "some students are still uncomfortable with computers and may not have easy access to the Internet" and people are too busy/distracted - "it is very time consuming for faculty and students" alike to teach and learn in the online environment [Abraham, 1995, p.147). Due to such problems, Pace University professors Sachs and Hale (2003, p. 2) recommend a combination of "online testing workshops, enhanced student support services, and mentoring" to increase student satisfaction with distance education.

Another con to online courses as viewed by faculty is that "students can cheat" by finding sources on the internet, using their books during the exams, having someone else take their exams for them or plagiarizing other people's work (Carnavale, 2001, p. A47). Often online students are working adults who have spent time in the work world and typically are older and believed to be "far less prone to cheat then the younger audience" (Mallory, 2001, p. 4). As online courses and programs increase, there will be greater potential for abuse since younger students are far more inclined to cheat and have more technological savvy to find creative ways to 'beat the system' in the online environment. Kerka \& Wonacoot (2000) agree that it is becoming more difficult to identify online cheating and impersonation is perceived as a greater risk. 


\section{Pros and Cons of Online Testing}

Benefits of online testing are numerous: "immediate results to faculty and students, and no loss of exams or compromising security by mailing or faxing" (Lorenzetti, 2006, p. 5), the convenience of taking a test whenever and wherever a student wants, getting immediate feedback, and adaptive testing (where the computer gives progressively harder questions in quizzes) (Sjoer and Dopper, 2003).

In the traditional class setting, testing with a professor provides face to face contact between faculty and students, clearer test instructions, direct supervision of students, and fast feedback on performance (depending on the professor). However the cons to the traditional classroom are that some professors may take too long to grade tests and give back results (Lorenzetti, 2006, p. 5). This is in direct contrast to the online testing environment which results in nearly immediate test results for multiple choice questions (automated systems) and fairly quick and more detailed feedback to students on other types of questions such as short answer or essays.

Concerns about online testing from faculty are widely voiced and include the following: 1) ensuring the student's identity (is student taking the test him/herself or getting outside help?), 2) discomfort of faculty with technology; 3) can online tests evaluate difficult concepts?, 4) how does online testing limit student's options?, 5) how can qualitative results be determined online?, 6) will wording on online test affect students' responses?, 7) ease of technology for student use; 8) ease and timeliness of data collection, and 9) difficulty of administering an online test (Mallory, 2001, p. 2).

\section{Successful Online Student Profile}

Students in distance education need to be self starters and have good study skills. Distance courses have the advantage that work assignments can be done at the student's pace and workload can be arranged to fit the student's work schedule (such as job related travel) more easily. Chang (2005) found in his research that students in a Webbased course have more positive motivational orientations and are more self-directed if they have specific instructions on learning strategies in their orientations to online courses.

In addition, students currently who take on-line courses have been seen to have "unique characteristics" and are often profiled as being "older", having "more work experience", enrolled in more non-traditional degree programs, have longer commutes, "have more childcare responsibilities", and "greater computer experience" in general, according to Dutton et al. (2002, p. 1).

On the other hand, for students who struggle with reading, writing, and comprehending concepts, distance education can be very demanding since students need stronger written communication skills, a higher comfort level with technology, to be well organized about due dates and must balance their time wisely to get all the online tasks completed. There is a tendency for some students to put off their assignments to the last minute as attested by the statistics in a tool like Blackboard; typically $30-50 \%$ of students wait until the last afternoon before the due date to submit an assignment online.

\section{Comparison of Communication Media}

In most communication courses, experts agree that face-to-face communications are a 'richer medium', meaning they are more appropriate for complex communications and for relaying messages that have high importance in people's lives, such as promotions, performance evaluations, bad news and criticism. This is primarily because in face-to-face communications, the listener can check to hear the words and also see the facial and nonverbal signals which communicate a bigger picture to the listener.

This is probably why many faculty still enjoy teaching in the classroom. However, there are times that written communications (which is the most relied upon communication in distance education) actually enhances learning and greater participation. For example, values are easier to discuss in writing than orally since "inadvertent or arranged nonverbal signals are not so dominant" in the online environment (Chickerinag, 1996, p. 5). Also, students may enjoy the anonymity of the online environment since their race/ethnicity, their physical deficits (i.e. 
obesity, disabilities, dwarfism) and their lifestyle differences (i.e. attire, economic status, piercings, tattoos, hair colorings/cuts) will not be issues in the online environment nor will they play a role in the faculty's bias regarding their performance. In addition, students who must travel for their jobs, have different shifts or who have children are able to access the online courses anytime that is convenient to their individual schedules. A mother with 5 children said about her experience at Brenau University (i.e. located in Gainesville, Georgia): "It would have been impossible for me to dream of completing an MBA before Brenau went online with its program." (In Class, Online).

\section{Best Practices in Assessment}

As online education is becoming more mainstream, the need to assess teaching in the online environment increases. There are a number of "best practice" recommendations for teaching methodologies in the online environment as researched by Chickering \& Ehrmann (1996):

Good practice \#1 - Encouraging contacts between faculty and students. The online environment can "strengthen interactions with all students, but especially with shy students who are reluctant to ask questions or challenge the professor directly." (1996, p. 4).

Good practice \#2 - Structure more interactions with other students; study groups, and group discussions in an online course; this can be a source of collaborative learning and group problem solving. A "clear advantage of email for today's busy commuting students is that it opens up communications with classmates even when they are not physically together (1996, p. 5).

Good practice \#3 - Use active learning; having students do research on the internet gives practical hands-on experience to students right in the online environment and taking online courses increases the student's facility with technology (1996, p. 5).

Good practice \#4 - Give prompt feedback; professors using online testing allows nearly immediate feedback for students on objective tests and usually much faster feedback on qualitative tests such as essays or case analysis; tracking changes on papers can provide learning opportunities for students in improving their papers; email can be used for more private and customized feedback to individual students or the discussion board can be used to give more general comments for all students to learn from; computers can be used for portfolio evaluations so faculty and students can see how students have gained in knowledge or improved their performance (1996, p. 6).

Since students vary in their readiness for the online environment, universities may want to assess the specific study skills of each student and screen those who do not have the needed skills to perform well in the online environment (Wadsworth et al., 2007, p. 13). Developing the skills needed for self-study and online learning as well as an overall orientation to the online course materials/content management system is recommended as a "best practice", which has some empirical research confirming its effectiveness. In their study, Wadsworth et al. (2007) found that students in a developmental online math course scored significantly higher in their final grade for the course if they had higher motivation, concentration, information processing and self-testing strategies. "Providing real examples and practice to students on how to transfer strategies from a traditional to an online classroom can give students tools to ensure success in the online classroom" (Wadsworth et al., 2007, p. 12).

Another 'best practice' is for professors in online courses to use a variety of measures to assess learning outcomes to compensate for a lack of face to face interaction (Chandra and Fisher, 2009; Chang et al., 2008). Dr. Iyengar (2003, p. 5) uses the following techniques: weekly online quizzes, discussion postings, optional chat comments on the learning experience (like a journal), proctored tests and test analysis.

For instance, in test analysis, Iyengar (2003) gives students the breakdown of the percentages of students who incorrectly answered certain questions and asks why students think they got the question wrong. This helps him to explain the concepts in further detail to those who may have not clearly understood it in that class and to improve his teaching for the next group. This interchange also encourages students to "take responsibility for their learning" Iyengar (2003, p. 5) believes. 
An additional way to offset one of the biggest drawbacks to distance education (i.e. the lack of face-to-face feedback, both verbal and non-verbal) is to enrich the online environment (Iyengar, 2003, p. 5). For example, encouraging each student to bring examples from the real world that collaborate what they have read or what points were made in a Powerpoint, or doing research via the internet and providing links to the rest of the class on a particular concept or way to solve a problem, can add value to online delivery of courses.

As online instructors can no longer monitor and react to student questions, comments, asides, body language, and facial expressions, they must employ other techniques to acquire the same information (Alessi and Trollip, 2001). The absence of low level social cues and emotions may minimize the richness of communication, limit and impede a more interactive cyber learning community (Robles and Braathen, 2002; Innovations...., 1999; Jung, 2001; Kerka and Wonacoot, 2000). Instead of using narrowly defined learning outcomes tested by examinations, technology offers a rich environment where skills such as written communication, collaboration, team work, and reflective thinking can be assessed by giving learners multiple channels, group/general discussion boards/tolls and unlimited space of expression. Technology can be used to create environments for assessment of learning (Banta et al., 1996; Black and William, 1998; Born, 2003; Broadfoot et al., 2001; Brookhart, 1997; Elwood and Klendowski, 2002; Hricko and Howell, 2005).

However, despite these opportunities in distance education, there are still some differences between online versus traditional course delivery and professors as well as experts continue to grapple with the recommendations for 'best practices' in their individual disciplines (Liang and Creasy, 2004; Meyer, 2002; Michlitsch and Sidle, 2002; Popham, 2002; Ryan, 2000). One area that administrators struggle with is what elements of distance education should be controlled by the structure and policies of the university or departmental unit and which parts of course development should be the academic freedom of the professor.

For example, do administrators limit the enrollments of online classes? Mallory (2001, p. 3) recommends that to successfully gain a rapport in the online environment "no more than 15-20 students be in an online class". In an attempt to increase the quality and consistency of online learning, some schools, like Troy University, have created policies that all online professors must return e-mails within 24 hours during the week and 48 hours on the weekend, have employed full time administrators and staff just for online students, and have a required template for all online syllabi which spells out details such as how many external links must be on Blackboard, where students get a proctor, required online course evaluations and what responsibilities the students/faculty have in online courses (www.troy.edu).

Rowe (2004, p. 6) also suggests several 'best practice' methodologies to increase the effectiveness of often criticized online assessments including: 1) explain what is meant by cheating or plagiarism and encourage honesty through honor codes or signed integrity policies; 2) "maintain assessment security" through difficult to guess instructor passwords and make frequent copies of grades (from the electronic gradebook) to guard against changes not made by the instructor; 3 ) use proctored tests for all important assessments and proctors who are "not personally related" to the students; 4) draw randomly generated questions from a large question pool and if possible, reorder the multiple choice answers as well; and 5) control the assessment situation by prohibiting all electronic devices from being in the testing room and disabling printers, internet access, and both hardwired and wireless networks.

\section{Comparison of Academic Rigor}

Often faculty question whether an online course has the same academic rigor of a traditional class in terms of testing and learning outcomes. Faculty are suspicious of online testing since un-proctored tests (often used in the online environment) are considered to be easier or less rigorous than proctored tests and students may be getting assistance on tests or cheating by getting the answers/questions from friends, or having friends take the exams for them (identity issues) (Mallory \& Laury, 2001; Trenholm, 2007; Williams et al., 2006, A Sense ..., 2006). In other words, students may earn a high mark on an online test but not really learn the material.

Suskie (2000, p. 4) recommends that learning outcomes need to be clearly stated, assessments should be tied directly to what is taught, and that faculty should build rapport with students through engaging and frequent 
assessments (i.e. use "many different measures and many different kinds of measures") of skills/concepts throughout the course.

In two sections of his introductory Management Information Systems (MIS) class, Dr. Abraham (1998, p. 12) found that the students in his online section "performed slightly better than students from another section taught in a conventional classroom setting". In addition, "students are more enthusiastic about the course, make better presentations, and occasionally make helpful suggestions that improve the class" (Abraham, 1998, p. 16). Dr. Abraham's experience supports the contention that the online environment can be a highly interactive and engaging learning experience for students, if structured successfully.

The online environment can also be more conducive to offering students extra study quizzes, self testing and study guides. The student generally has more responsibility to take the initiative for their own learning in this venue. To test this assumption of more self discipline and its relationship to performance, Kibble (2007, p. 258) found that "students who used formative assessment generally performed better on summative examinations" and "providing incentives for online quizzes increased student participation." Formative assessment, in this case, means that un-proctored quizzes were taken repeatedly to prepare for the proctored midterm and final exams.

Wellman (2005, p. 25) discovered in his research on 120 college students in a Doctor of Pharmacy program at Ferris State University that on-line delivery paired with proctored testing was more effective in promoting learning than un-proctored testing as measured by "improvement from medical terminology pre-test to post-test". In an earlier study, Wellman and Markcinkiewicz (2004) also showed that proctored tests used alongside un-proctored quizzes (which they identified as "more time on task") increased student performance on terminology tests. Alexander et al. (2001, Online) compared proctored pen and pencil tests to proctored online tests and found no significant differences in the performance of students. Here the operative word is "proctored".

Contrary to Abraham's study which used MIS classes to compare online and on-ground students, Lawrence and Singhania (2004, p. 336) discovered strong evidence that traditional students outperformed the distance learning students on tests (multiple choice and written) and overall grade (by .259 margin in 11 classes) ( $\mathrm{p}=.0036$ ). Also there was a "moderate difference in the percentage of students" who did not finish the class and those who received a D or F, or withdrew (W or WF) was greater in the distance-learning courses than the traditional ones $(\mathrm{p}=.0339)$ (2004, p. 336). There is one caveat, from 2001 to 2003, students have been getting better in test scores and grades over time in the distance education sections.

Unlike the "typical" online student who is older and non-traditional, most of the students were traditional aged (in their early 20s) in their sample. As students took more online courses, they found that students become better at taking online classes (Lawrence and Singhania, 2004, p. 337). What happened in the Lawrence and Singhania's (2004) research is that students who could not get into the traditional on-ground class were given the option to take a second section of the course which was totally online. If they didn't take the course online, they would have to wait another semester to get the course. So, in essence, by the structuring of their scheduling of courses, administrators/faculty were 'forcing' students to elect 'online' course formats when they may not have been ready for and/or they actually preferred the traditional classroom format.

\section{Comparison of Proctored and Un-proctored Tests}

When comparing an un-proctored to an on-ground or online proctored test, faculty in general feel that students do not get the same level of testing. Overall, the concern of faculty is that "un-proctored, on-line, asynchronous testing would be compromised by students collaborating without consent of the instructor" (McCabe, 2001, p. 219). Students themselves admit that the "absence of supervision" is a factor which has influenced them to cheat (Whitley, 1998, p. 235). Even with proctored tests, students may find a way to cheat. Their friends may take the test early and share their results so that late testers do better on the tests than early test takers. One way to address this problem Olt (2002, Online) says is for faculty to create assessment questions which are "drawn from a large pool and each student is given a randomly generated selection" of questions on an individual test. Such test construction is currently facilitated on management software such as Blackboard and WebCT. 
To decide on the efficacy of proctored versus un-proctored tests, academe would do well to benchmark what the corporate world has deemed as 'essential' in testing. "Because vendors such as Cisco and Microsoft want to ensure the validity of certifications bearing their names, they insist that exams be taken in brick-and-mortar facilities run by companies such as Sylvan Learning and Prometric. Test takers must show up with two forms of ID and proctors must watch them take exams (Raths, 2001, p. 44). Proctors are charged with checking the student's identity (Lorenzetti, 2006, p. 5). "Proctored tests also help satisfy accrediting agencies that colleges are offering sound programs" since many accreditation groups have questioned the effectiveness of un-proctored testing (Young, 2001, p. A43). Test centers also monitor screen content by using software (such as Blackboard) that prevents students from browsing the internet during the test, times the test, and verifies the student's identity (eg. Remote proctoring uses fingerprints and photo id scanners while live proctors visually check photo ids). Lorenzetti (2006, p. 6) suggests that tests be protected by a password which only the proctor or test center receives as an added precaution.

\section{METHODOLOGY}

\section{Sample}

The sample size consisted of 76 students at Troy University, including the Georgia and Virginia campuses, who attended four business graduate level courses online. Three faculty members in Finance, Marketing and Management gave both proctored and non-proctored tests in their respective online courses: MGT 6600 in Terms 1 and 2, 2007; HSA 6682 in Term 5 2007; and MBA 6631 in Term 3, 2008. These students' scores were compared in the first phase of a general comparison between proctored and non-proctored tests, despite course and instructor differences. Two of the graduate courses, the MGMT 6600 courses, were taught by the same faculty member, who used similar proctored and non-proctored tests, the same textbook, and the same course materials. As a second phase of the research, this group of students were also statistically analyzed for differences based on the type of testing conducted $(\mathrm{N}=47)$.

\section{Statistical Testing}

One-tailed t-tests were performed on the four classes as a whole to see if the average test scores for students who took proctored exams were different from the scores for the non-proctored tests. The four classes were in 3 different disciplines, namely Advanced Theory and Concepts of Management (offered for two different semesters in 2007), Health Care Management and Financial Management courses. All students were taking classes online at Troy University from Term 1, 2007 to Term 3 in 2008.

In addition, t-test statistical tests (one-tailed) were conducted on the two classes which were the same with the same instructor using tests that were randomly generated from the same test bank pool. The means, standard deviation and standard error of the mean as well as $t$ test results are given. The researchers also filed and were approved to present the findings internally in March, 2008 and to publish the findings through academic conferences and journals in June, 2008 by the Institutional Review Board (IRB) of Troy University.

\section{RESULTS AND DISCUSSION}

\section{Results}

In the first comparison (using all the students in all four classes), the authors found the means of the proctored tests were $79 \%$ whereas the non-proctored test average was $87 \%$ with standard deviation of 14.422 and 9.750 respectively. Standard Error of the Mean was 1.654 for proctored tests and 1.118 for non-proctored tests (Please see Table 1 for the results).

Table 2 summarizes the one-tailed t- test results showing highly significant $(\mathrm{p}<.000)$ differences in average test scores for proctored versus (87\%) versus non-proctored tests (79\%). 
Table 1: Mean, Standard Deviation, and Standard Error of the Mean of Proctored vs. Non-Proctored Average Test Scores for Graduate Business Courses at Troy University

\begin{tabular}{|l|r|r|r|c|}
\multicolumn{7}{|c}{ One-Sample Statistics } \\
\hline & $\mathrm{N}$ & Mean & Std. Deviation & $\begin{array}{c}\text { Std. Error } \\
\text { Mean }\end{array}$ \\
\hline Proctored Tests & 76 & 79.18 & 14.422 & 1.654 \\
NonProctored & 76 & 87.30 & 9.750 & 1.118 \\
\hline
\end{tabular}

Table 2: T-Test Results of Proctored vs. Non-Proctored Average Test Scores for Graduate Business Courses at Troy University

\begin{tabular}{|c|c|c|c|c|c|c|}
\hline \multicolumn{7}{|c|}{ One-Sample Test } \\
\hline & \multicolumn{6}{|c|}{ Test Value $=0$} \\
\hline & \multirow[b]{2}{*}{$t$} & \multirow[b]{2}{*}{ df } & \multirow[b]{2}{*}{ Sig. (2-tailed) } & \multirow{2}{*}{$\begin{array}{c}\text { Mean } \\
\text { Diff erence }\end{array}$} & \multicolumn{2}{|c|}{$\begin{array}{l}95 \% \text { Confidence } \\
\text { Interv al of the } \\
\text { Diff erence }\end{array}$} \\
\hline & & & & & Lower & Upper \\
\hline Proctored Tests & 47.865 & 75 & .000 & 79.184 & 75.89 & 82.48 \\
\hline NonProctored & 78.058 & 75 & .000 & 87.303 & 85.07 & 89.53 \\
\hline
\end{tabular}

In order to control for the variance due to differences in instructors and courses, the two classes (of the same course), which were taught by the same instructor, using the same text, similar Blackboard formats online, and similar tests drawn from a random test bank pool, were analyzed. The results were comparable to the general results (for all 4 courses, $\mathrm{N}=76$ ) as found in Table 2. The average test score for proctored exams was $74 \%$ and $86 \%$ for non-proctored for the two MGMT 6600 courses $(\mathrm{N}=47)$ as shown in Table 3. Again the proctored test scores on average were significantly lower than the non-proctored scores $(\mathrm{p}<.000)$. Please see Table 4 for the complete results of the t-test of the MGMT 6600 (Advanced Theory and Concepts in Management) course only.

Table 3: Mean, Standard Deviation and Standard Error of the Mean of Proctored vs. Non-Proctored Average Test Scores for Graduate Course MGMT 6600 Advanced Concepts in Management at Troy University

One-Sample Statistics

\begin{tabular}{|l|r|r|r|r|}
\hline & $\mathrm{N}$ & Mean & Std. Deviation & $\begin{array}{c}\text { Std. Error } \\
\text { Mean }\end{array}$ \\
\hline Proctored Tests & 47 & 74.17 & 13.620 & 1.987 \\
NonProctored & 47 & 86.09 & 9.987 & 1.457 \\
\hline
\end{tabular}

Table 4: T-Test Results of Proctored vs. Non-Proctored Average Test Scores for Graduate Course MGMT 6600 Advanced Concepts and Theories in Management at Troy University

One-Sample Test

\begin{tabular}{|c|c|c|c|c|c|c|}
\hline & \multicolumn{6}{|c|}{ Test Value $=0$} \\
\hline & \multirow[b]{2}{*}{$\mathrm{t}$} & \multirow[b]{2}{*}{ df } & \multirow[b]{2}{*}{ Sig. (2-tailed) } & \multirow{2}{*}{$\begin{array}{c}\text { Mean } \\
\text { Diff erence }\end{array}$} & \multicolumn{2}{|c|}{$\begin{array}{l}95 \% \text { Confidence } \\
\text { Interv al of the } \\
\text { Diff erence }\end{array}$} \\
\hline & & & & & Lower & Upper \\
\hline Proctored Tests & 37.335 & 46 & .000 & 74.170 & 70.17 & 78.17 \\
\hline NonProctored & 59.096 & 46 & .000 & 86.085 & 83.15 & 89.02 \\
\hline
\end{tabular}




\section{Discussion}

The present research gives credence to the assumption that online course rigor can be enhanced by requiring proctored exams. The evidence in this study shows significant differences in test results (ranging from 812 percentage point differences in test scores depending on the course). Based upon the findings of this research and the literature review, the authors make the following recommendations for future testing in the online environment:

1. Use more proctored tests in online courses

2. Use qualitative or subjective assignments such as written essays and papers with a rubric for assessment as well as enriching activities such as internet exercises.

3. Have protocol for proctors in taking 2 forms of id.

4. Have stricter guidelines for who can be proctors (i.e. students should not use their friends, relatives, or immediate supervisors as proctors)

5. Use non-proctored tests on a more limited basis, preferably for quizzes or study reviews, or tests which are not a significant percent of the grade. Incentives to use non-proctored tests to prepare for proctored tests can be given as extra credit points or bonus points to encourage this type of self study.

\section{Limitations and Future Research}

Issues which limit the present study include: 1) use of test scores only; 2) limited usage of different types of proctoring (i.e. live vs. remote proctoring); 3) comparison across courses and professors; 4) small sample and cell size and 5) generalizability. The authors used only test scores in their current research but could investigate if course grades were actually lower when professors used proctored exams. Ideally, the number of proctored tests (or the percentage of the total grade) could be examined to see if there is a threshold for impacting a student's course grade.

Originally the researchers became interested in the impact of a new policy implemented in Term 1, 2007 (August): All professors who taught online graduate business courses at Troy were required to give one (1) proctored exam per term. In Term 1, 2008, Troy University also initiated a pilot study of a remote proctor system called 'Secureexam Remote Proctor System' (A Sense ...2006). Three professors implemented the remote proctor system at that time but only one professor participated in the current study. Since there were only 8 students who used the remote proctoring system, the authors were unable to compare remote versus live proctored test results, which would be a worthwhile follow-up study.

The one drawback to using remote proctoring as gleaned from the professor who was in the pilot study and participated in this research, is the amount of time it takes the professor to get the system up and running, time to review the videotapes of the test taker (the remote system does give the professor hints as to what behavior, such as noises and motions, is suspicious and which frames on the videotape to watch), and the cleverness of students to deceive the remote proctoring system. The benefits of the remote proctoring system are: 1) low cost of approximately $\$ 150 ; 2$ ) increased security using fingerprint and student id scanning; and 3) ease of use in any location (particularly useful for military personnel who may be deployed in the middle of a course and distant from any test center/proctoring sites).

Although the overall study was conducted across courses and professors, the subset study of the test scores from one professor who controlled for the text, test questions and teaching methods, shows comparability. However, these results could be suspect due to the small sample size. There were only 76 students in the larger sample and 47 students in the one professor, one course sample. To increase the reliability of the results, the authors suggest using a larger sample size. If possible, it would be best to compare professors who are teaching the same course using the same textbook and again to increase this database so that both sample and cell size are not issues.

Lastly, the research was only conducted in one university. It is highly recommended to increase the generalizability of the study by gathering data from a number of different universities employing distance education. It would be interesting to check on differences between universities based on size, location and missions. Another factor to control for would be the extent of the distance education: Is the student taking one course via distance education or is their entire program online? 


\section{CONCLUSIONS}

In conclusion, the authors found that in different courses with different professors, there were consistent results that demonstrated the effectiveness of proctored exams. By having a proctor, professors will experience a more rigorous assessment which would be more comparable to the traditional classroom test environment. To increase the academic rigor of online classes and to enhance the comparability of online education to traditional teaching, the researchers have convincingly brought evidence to show that students who take proctored tests will perform statistically lower on their tests as compared to students who are given non-proctored tests. In addition, the study gives a quantitative review of "best practices" for assessments in distance education, which includes increased use of proctored exams, random question pools, additional identity checks and using un-proctored tests for study or quiz purposes which are not heavily weighted in the final grade.

\section{AUTHOR BIOGRAPHIES}

Dr. Prince is presently the Associate Dean of the School of Business at Clayton State University in Morrow, Georgia. Previously, she was the Dean of the School of Business at Brenau and Program Manager for Business at Troy University in Augusta, Georgia. Diane completed her Ph.D. in Strategic Management and International Business at the University of Tennessee-Knoxville. Dr. Prince has taught in MBA and Executive MBA programs in Singapore, Malaysia, Hong Kong and Indonesia. She has been extensively published in journals including Planning Review, Organizational Dynamics, Journal of Small Business Management, and Journal of Marketing and Management Research.

Assistant Professor Richard Fulton teaches computer science and information systems courses on ground and online at Troy University in Augusta, Georgia. He is the Program Manager for all undergraduate students in computer science. He graduated from Illinois State University in computer science and was an Instructor in their Computer Science Department. Previous to that, he was an owner of a construction company in Illinois.

Dr. Thomas Garsombke, an Assistant Professor, teaches marketing and management at Claflin University in SC and has his doctorate from Northeastern University in Boston. He has been the author of numerous books and several chapters in monographs. In addition, his articles have appeared in the Academy of Entrepreneurship Journal, Journal of Business Strategies and the Journal of Small Business Management. He has been a Visiting Professor and consultant to the Far East.

\section{REFERENCES}

1. Abraham, Thomas, The Interactive and Integrated MIS Classroom: Using Presentation and Group Support Software to Create an Active Learning Environment, Journal of Information Systems Education, Vol. 1, No. 7, pp. 144-147, 1995.

2. Abraham, Thomas, The Interactive, Virtual Management Information Systems (MIS) Classroom: Creating an Active Learning Environment on the Internet, WebNet 98 World Conference of the WWW, Internet and Intranet Proceedings, November 7-12, Orlando, Florida, pp. 11-18, 1998.

3. Alessi, S. M.and S. R. Trollip, Tests and Multimedia for Learning: Methods and development, $3^{\text {rd }}$. edition, Allyn \& Bacon, Boston, 2001.

4. Alexander, M., Bartlett, J. E., Truell, A.C. and K. Ouwenga, Testing in a Computer Technology Course: An investigation of Equivalency in Performance Between Online and paper and Pencil Methods. Journal of Career and Technical Education, 2001, Vol. 18, No. 1, Fall, Online, www.shcolar.lib.vt.edu/ejournals/JCTE/v18n1/alexander.html.

5. Banta, T. W., Lund, J. P., Black, K. E., and F. W. Oblander, Assessment in Practice: Putting Principles to Work on College Campuses, Jossey-Bass, San Francisco, 1996.

6. Black, P. and D. William, Inside the Black Box: Raising Standards through Classroom Assessment, Phi Delta Kappan, 1998, Vol. 80, No. 2, pp. 139-148.

7. Born, A.D. Web-Based Student Assessment, WebBased Education: Learning from Experience, IGI Publishing, Hershey, PA, 2003. 
8. Broadfoot, P., Osborn, M., Sharper, K. and C. Planel, Pupil Assessment and Classroom Culture: A Comparative Study of Language of Assessment in England and France, in Scott, D. (Ed.): Curriculum and Assessment. Ablex Publishing, Westport, CT, 2001.

9. Brookhart, M., S., A Theoretical Framework for the Role of Classroom Assessment in Motivating Student Effort and Achievement, Applied Measurement in Education, Vol. 10, No. 2, pp. 161-180, 1997.

10. Carnevale, Dan, How to Proctor From a Distance, Chronicle of Higher Education, Vol. 46, No.12, pp. A47-A48, 1999.

11. Carnevale, Dan, Assessment Takes Center Stage in Online Learning, The Chronicle of Higher Education, Vol. 47, No. 31, pp. A43-A45, 2001.

12. Chandra, V. And Fisher, D. L., Students' Perceptions of a Blended Web-based Learning Environment. Learning Environment Research, Vol. 12, pp. 31-44, 2009.

13. Chang, M., Applying Self-regulated Learning Strategies in a Web-based instruction: An Investigation of Motivation Perception. Computer Assisted Language Learning, Vol. 18, pp. 217-230, 2005.

14. Chang, C. K., Chen, G. D., and L.Y. Li, Constructing a community of practice to improve coursework activity, Computers \& Education, Vol. 50, pp. 235-247, 2008.

15. Chickering, Arthur W. and Stephen C. Ehrmann, Implementing the Seven Principles: Technology as Lever. AAHE Bulletin, October, pp. 3-6, 1996.

16. Dutton, J.; Dutton, M. and J. Perry, How Do Online Students Differ from Lecture Students? Journal of Asynchronous Learning Networks, Vol, 6, pp.1-20, 2002.

17. Elwood, J. and V. Klendowski, Creating of Shared Practice: The Challenges of Assessment Use in Learning and Teaching, Assessment \& Evaluation in Higher Education, Vol. 5, No. 3, pp. 243-256, 2002.

18. Frederiksen, J. R., and B. J. White, "Reflective Assessment of Students' Research within an Inquiry-based Middle School Science Curriculum, Paper presented at the annual meeting of the American Educational Research Association, Chicago, IL, 1997.

19. Hricko, Mary and Scott L. Howell. Online Assessments and Measurement: Foundations and Challenges [electronic resource], Information Science Publisher, Hershey, PA, 2005.

20. Innovations in Distance Education, An Emerging Set of Guiding Principles for the Design and Development of Distance Education, Pennsylvania Sate University, Pennsylvania, Retrieved from (September 24 2002): http://www.outreach.psu.edu/de/ide, 1999.

21. Iyengar, Sridharan, Getting the Most Out of Standard Assessment Measures, Distance Education Report, Vol. 7, No. 19, pp. 5-6, 2003.

22. Jung, I. Building a Theoretical Framework of Web-based Instruction in the Context of Distance Education, British Journal of Educational Technology, Vol. 32, No. 5, pp. 525-534. 2001.

23. Kerka, S. and M. E. Wonacoot, Assessing Learners Online: Practitioner's File. Office of Educational Research, Washington, DC, (ERIC Document Reproduction Service No. ED448285), 2000.

24. Kibble, Jonathan, Use of Unsupervised Online Quizzes as Formative Assessment in a Medical Physiology Course: Effects of Incentives on Student Participation and Performance, Advances in Physiology Education, Vol. 31, pp. 253-260, 2007.

25. Lawrence, J. A., A Distance Learning Approach to Teaching Management Science and Statistics, International Studies in Operational Research, Vol. 10, pp. 1-13, 2003.

26. Lawrence, John A. and Ram P. Singhania, A Study of Teaching and Testing Strategies for a Required Statistics Course for Undergraduate Business Students, Journal of Education for Business, Vol. 7, No.96, pp. 333-338, 2004.

27. Liang, Xin and Kim Creasy, Classroom Assessment in Web-based Instructional Environment: Instructors' Experience, Practical Assessment, Research \& Evaluation, Vol. 9, No. 7, Retrieved March 23, 2009 from http://PAREonline.net/getvn.asp?v=9\&n=7, 2004.

28. Lorenzetti, J. P., Proctoring Assessments: Benefits \& Challenges, Distance Education Report, Vol.10, No. 8, pp. 5-6, 2006.

29. Mallory, James, Adequate Testing and Evaluation of On-line Learners, Instructional Technology and Education of the Deaf Symposium Proceedings, [Online Journal], June, http://www.rit.edu/techsym. 2001.

30. Martin, M. J., Survey of Online Faculty, RIT Technology Center Newsletter [Electronic Publication], Retrieved on April 22, 2009 on www.albert.rit.edu, 2001.

31. McCabe, D.L.; Trevino, L.K. and K.D. Butterfield, Cheating in Academic Institutions: A Decade of Research, Ethics \& Behavior, Vol. 11, pp. 219-232, 2001. 
32. Meyer, K. A., Quality in Distance Education: Focus on On-line Learning, Jossey-Bass, San Francisco, CA, 2002.

33. Michlitsch, J. F. and M. W. Sidle, Assessing Student Learning Outcomes: A Comparative Study of Techniques Used in Business School Discipline, Journal of Education for Business, Vol. 77, No. 3, pp. 125-30, 2002.

34. Olt, M., Ethics and Distance Education: Strategies for Minimizing Academic Dishonesty in Online Assessment, Online Journal of Distance Learning Administration, [Online], Vol. 5, No. 3, Available at: http://www.westga.edu/-distance/ofdla/fall53/olt53.html, 2002.

35. Phipps, R. and J. Merisotis, What is the Difference? A Review of Contemporary Research on the Effectiveness of Learning in Higher Education, Institute for Higher Education Policy, Washington, DC, 1999.

36. Popham, W. J., Classroom Assessment - What Teachers Need to Know, Allyn and Bacon, Boston, MA, 2002.

37. Raths, David, Testing the Limits, Network World, Vol. 18, No. 34, pp. 44-45, 2001.

38. Robles, M., and S. Braathen, Online Assessment Techniques, The Delta Pi Epsilon Journal, Vol. 44, No.1, pp. 5-15, 2002.

39. Rowe, N., Cheating in Online Student Assessment: Beyond Plagiarism, Online Journal of Distance Learning Administration [Online Journal], Retrieved on May 20, 2009 on www.westga.edu, 2004.

40. Ryan, R. C., Student Assessment Comparison of Lecture and Online Construction Equipment and Methods Classes, THE Journal, Vol. 27, No. 6, pp. 78-83, 2000.

41 Sachs, D. and N. Hale, Pace University's Focus on Student Satisfaction with Student Services Online Education. Journal of Asynchronous Learning Networks [Electronic version], Vol. 7,October, pp. 2-4. 2003.

42. Sherry, L., Bilig, S., Jesse, D., and D. Watson-Acosta, Instructional Technology on Student Achievement, THE Journal, Vol. 28, No. 7, pp. 40-46, 2001.

43. Sjoer, E. and S. M. Dopper, Are the Promises of Online Assessment being Proved in Practice? A Case Study into What Conditions Should be Met in Order to Use Online Assessment Successfully, Sefi Proceedings, May 24, 2003.

44. Stiggins, R., Student-Centered Classroom Assessment ( $2^{\text {nd }}$ edition), Merrill, Upper Saddle River, N.J., 1997.

45. Suskie, Linda., Fair Assessment Practices, AAHE Bulletin [Online Version], Retrieved on May 15, 2009 on www.aahe.org/bulletin/may2.htm, 2000.

46. Trenholm, Sven, A Review of Cheating in Fully Asynchronous Online Courses: A Math or Fact-based Course Perspective, Journal of Educational Technology Systems, Vol. 35, No. 3, pp. 281-300, 2007.

47. Wadsworth, L. M., Husman, Jenefer; Duggan, M.A., and M. N. Pennington, Online Mathematics Achievement: Effects of Learning Strategies and Self-efficacy, Journal of Developmental Education, Vol. 30, No. 3, pp. 6-14, 2007.

48. Wellman, Gregory, Comparing Learning Style to Performance in On-line teaching: Impact of Proctored v. Unproctored Testing, Journal of Interactive Online Learning, Vol. 4, No. 1, pp. 20-39, 2005.

49. Wellman, Gregory and Henryk Markcinkiewicz, Online Learning and Time-on-Task: Impact of Proctored vs. Un-Proctored Testing, Journal of Asynchronous Learning Networks [Online Journal], Vol. 8, December, pp. 45, 2004.

50. Whitley, B.E., Factors Associated with Cheating among College Students, Research in Higher Education, Vol. 39, pp. 235-274, 1998.

51. Williams, D.D.; Hricko, M. and S. L. Howell, Online Assessment, Measurement, and Evaluation [Electronic resource], Information Science Publisher, Hershey, PA, 2006.

52. Young, Jeffrey R., Texas Colleges Collaborate to Offer Online Students Convenient Proctored Tests, The Chronicle of Higher Education, Vol. 47, No. 26, p. A43, 2001.

53. Unauthored, A Sense of Security: Troy University Unveils Online Test Security System at SACS Meeting, Troy Today, January 6, p. 3. Retrieved on May 20. 2009 at http://www.troy.edu/news/troytoday/2006/1-06-06TROY\%20Today.pdf, 2006.

54. Unauthored, IT on the Campuses: What the Future Holds, Chronicle of Higher Education [Online Version], April 4, 2008. 